University of Nebraska - Lincoln

DigitalCommons@University of Nebraska - Lincoln

Faculty Papers and Publications in Animal

Science

Animal Science Department

2013

\title{
Nitrogen Input Effects on Herbage Accumulation and Presence of Pasture Plant Species
}

John A. Guretzky

University of Nebraska-Lincoln, jguretzky2@unl.edu

Walter Schacht

Laura Snell

Jonathan Soper

Stephanie Moore

See next page for additional authors

Follow this and additional works at: https://digitalcommons.unl.edu/animalscifacpub

Part of the Genetics and Genomics Commons, and the Meat Science Commons

Guretzky, John A.; Schacht, Walter; Snell, Laura; Soper, Jonathan; Moore, Stephanie; and Watson, Andrea, "Nitrogen Input Effects on Herbage Accumulation and Presence of Pasture Plant Species" (2013). Faculty Papers and Publications in Animal Science. 910.

https://digitalcommons.unl.edu/animalscifacpub/910

This Article is brought to you for free and open access by the Animal Science Department at DigitalCommons@University of Nebraska - Lincoln. It has been accepted for inclusion in Faculty Papers and Publications in Animal Science by an authorized administrator of DigitalCommons@University of Nebraska Lincoln. 


\section{Authors}

John A. Guretzky, Walter Schacht, Laura Snell, Jonathan Soper, Stephanie Moore, and Andrea Watson 


\title{
Nitrogen Input Effects on Herbage Accumulation and Presence of Pasture Plant Species
}

\author{
John A. Guretzky,* Walter Schacht, Laura Snell, Jonathan Soper, Stephanie Moore, \\ Andrea Watson, and Terry Klopfenstein
}

\begin{abstract}
Long-term responses of pasture plant species to management strategies that vary amount and form of $\mathrm{N}$ inputs form a knowledge gap. Our objective was to determine how supplementation of grazing beef cattle (Bos taurus) with corn (Zea mays L.) dried distillers grains plus solubles (DDGS) in unfertilized pasture (SUPP) affects annual herbage accumulation and presence of plant species and functional groups relative to unsupplemented beef cattle on unfertilized (CONT) and N-fertilized (FERT) smooth bromegrass (Bromus inermis Leyss.) pasture. We addressed this objective in the sixth (2010) and seventh (2011) years of a long-term experiment in eastern Nebraska, where $\mathrm{N}$ input from DDGS supplementation and urea fertilizer averaged 0,43 , and $90 \mathrm{~kg} \mathrm{ha}^{-1} \mathrm{yr}^{-1}$ within CONT, SUPP, and FERT, respectively. For these years, annual herbage accumulation averaged 6.87, 6.80, and $10.58 \mathrm{Mg} \mathrm{ha}^{-1}(\mathrm{LSD}=1.49)$ and $66.5,66.2$, and 76.0\% of herbage accumulated by 25 June $(\mathrm{LSD}=5.3)$ in CONT, SUPP, and FERT, respectively. Smooth bromegrass occurred in $99.8 \%$ of $0.1-\mathrm{m}^{2}$ pasture quadrats regardless of treatment. Cessation of $\mathrm{N}$ fertilizer input, however, increased presence of annual foxtail (Setaria spp.), annual graminoids, and annuals among quadrats in CONT relative to FERT. Supplementation of DDGS, while shown in previous studies to improve weight gains and N use efficiency in cattle, supplied enough $\mathrm{N}$ through excretion to provide an intermediate level of resistance to annual weeds. Nitrogen excreted from cattle supplemented with DDGS, however, did not affect herbage accumulation in subsequent years.
\end{abstract}

$S^{n}$ MOOTH BROMEGRASS IS a major pasture grass in the north central region of the United States and was one of a few cool-season grasses that persisted through the drought of the 1930s while providing perennial grass coverage to highly erodible lands (Vogel et al., 1996). In eastern Nebraska, forage yields of smooth bromegrass are typically maximized with application of 90 to $135 \mathrm{~kg} \mathrm{~N} \mathrm{ha}^{-1}$ (Colville et al., 1963). With rising costs of applying $\mathrm{N}$ fertilizer, increasing awareness of $\mathrm{N}$ losses to the environment, and pasture acreage as a whole decreasing, efforts have been underway to increase $\mathrm{N}$ use efficiency in forage and livestock production systems. Symbiotic N fixation between legumes and soil rhizobia provides a mechanism to reduce $\mathrm{N}$ fertilizer use in smooth bromegrass pasture (Sleugh et al., 2000; Harmoney et al., 2001), but unreliable production and poor persistence of legumes in pasture often limits their use (Beuselinck et al., 1994).

In recent years, by-products from the ethanol industry including corn DDGS have become available, and their use in feedlot and pasture systems has provided an excellent source of crude protein and digestible dry matter while substituting for forage in beef cattle diets (Klopfenstein et al., 2008).

J.A. Guretzky, W. Schacht, L. Snell, and J. Soper, Univ. of Nebraska-Lincoln, Agronomy and Horticulture, 202 Keim Hall, Lincoln, NE 68583-0915; S. Moore, A. Watson, and T. Klopfenstein, Univ. of Nebraska-Lincoln, Animal Science, C203 ANSC, Lincoln, NE 68583-0908. Received 27 Nov. 2012.

*Corresponding author (jguretzky2@unl.edu).

Published in Agron. J. 105:915-921 (2013)

doi:10.2134/agronj2012.0458

Copyright (c) 2013 by the American Society of Agronomy, 5585 Guilford Road, Madison, WI 53711. All rights reserved. No part of this periodical may be reproduced or transmitted in any form or by any means, electronic or mechanical, including photocopying, recording, or any information storage and retrieval system, without permission in writing from the publisher.
Experiments have reported linear and quadratic increases in average daily body weight gains and final body weight of steers, respectively, with DDGS supplementation on pasture (Griffin et al., 2012). In 2005, an experiment was initiated in Nebraska to evaluate whether supplementation of DDGS to beef cattle grazing unfertilized smooth bromegrass pasture could replace forage in diets, improve $\mathrm{N}$ use efficiency, and be cost effective relative to unsupplemented cattle grazing $\mathrm{N}$-fertilized and unfertilized pastures (Greenquist et al., 2009, 2011; Watson et al., 2012). The experiment showed that average daily weight gain and total weight gain per hectare of steers supplemented with DDGS on unfertilized smooth bromegrass pasture (SUPP) exceeded those of unsupplemented steers on unfertilized (CONT) and N fertilized (FERT) smooth bromegrass pasture. Steers consumed less forage in SUPP, but total $\mathrm{N}$ intake and retention was greater on per steer and per hectare bases in SUPP than in CONT and FERT (Greenquist et al., 2011).

As efforts are made to improve $\mathrm{N}$ use efficiency in forage and livestock production systems, questions arise about ecosystem responses to management strategies that vary amount and form of $\mathrm{N}$ inputs. In 2010, the DDGS supplementation experiment on smooth bromegrass pasture in Nebraska remained ongoing and presented an opportunity to evaluate vegetation and soil responses to management strategies. The objective of this study was to determine whether long-term supplementation of grazing beef cattle with DDGS on unfertilized pasture affected annual herbage accumulation and presence of pasture plant species and functional groups relative to CONT and FERT pastures.

Abbreviations; AUD, animal unit days; AUM, animal unit month; CONT, unfertilized control; DDGS, dried distillers grains plus solubles; FERT, nitrogen fertilized; SUPP, unfertilized with cattle supplemented with dried distillers grains plus solubles. 
Although we did not evaluate presence of pasture plant species until the sixth (2010) and seventh (2011) years of the experiment, all treatment pastures were fertilized at $90 \mathrm{~kg} \mathrm{~N} \mathrm{ha}^{-1} \mathrm{yr}^{-1}$ for decades, and presumably started with the same composition, before initiation of the experiment in 2005 (Greenquist et al., 2009). We hypothesized that $\mathrm{N}$ excretion through cattle supplemented with DDGS containing $43 \mathrm{~kg} \mathrm{~N} \mathrm{ha}^{-1} \mathrm{yr}^{-1}$ (SUPP), would increase annual herbage accumulation relative to CONT and maintain similar pasture plant species as FERT.

\section{MATERIALS AND METHODS}

\section{Experiment Location and Treatments}

Research was conducted within an ongoing pasture experiment at the University of Nebraska Agricultural Research and Development Center near Mead, NE $\left(96^{\circ} 33^{\prime} \mathrm{W}, 41^{\circ} 11^{\prime} \mathrm{N}\right)$ where body weight gains of beef cattle have been recorded among FERT, SUPP, and CONT systems since 2005 (Greenquist et al., 2009; Watson et al., 2012). The experiment was a randomized complete block design consisting of three blocks and three pasture treatments that served as experimental units. Treatments included unfertilized CONT pasture stocked initially with steers at 192 animal unit days (AUD) ha ${ }^{-1}$, unfertilized SUPP pasture stocked initially at $276 \mathrm{AUD} \mathrm{ha}^{-1}$ while steers were supplemented from a bunk with $2.7 \mathrm{~kg}$ $\mathrm{AUD}^{-1}$ of DDGS (dry matter basis), and FERT pasture with $90 \mathrm{~kg} \mathrm{~N} \mathrm{ha}^{-1}$ applied annually as urea and stocked initially with steers at $276 \mathrm{AUD} \mathrm{ha}^{-1}$ (Table 1). The initial stocking rates for CONT and FERT pastures were based on suggested initial stocking rates for smooth bromegrass in eastern Nebraska (Waller et al., 1986) and data supporting 30\% less herbage production in unfertilized stands of smooth bromegrass (Colville et al., 1963). The initial stocking rate of SUPP pasture was based on research that showed supplementation of DDGS to grazing cattle replaced forage at $0.79 \mathrm{~kg} \mathrm{DM} \mathrm{kg}^{-1}$ of DDGS supplemented (Greenquist et al., 2009; Watson et al., 2012).

Each of the nine experimental units were split into six paddocks and rotationally stocked from 19 April to 12 September in 2010 (147 d) and 19 April to 4 October in 2011 (168 d). Grazing was initiated during rapid pasture growth in spring and terminated in early fall to allow smooth bromegrass to recover before winter. The grazing season was cut short in 2010 by a hailstorm on 13 September. The experimental units with their six paddocks were 2.01 ha for FERT and SUPP and 2.90 ha for CONT to achieve recommended initial stocking rates (Table 1). There were five cycles of grazing per year in each set of six paddocks. During the first cycle in spring while smooth bromegrass growth was most rapid, cattle were moved among paddocks every $4 \mathrm{~d}$. From the second through the fourth cycles, cattle were moved to the next paddock every $6 \mathrm{~d}$. During the fifth cycle, grazing period length for a paddock was 4 to $6 \mathrm{~d}$ depending on year and herbage accumulation.

Stocking density varied across the season as put-and-take cattle were used to maintain comparable grazing pressure among treatments and years (Table 1). With the use of put-and-take animals, the end-of-season herbage mass goal of $1200 \mathrm{~kg} \mathrm{ha}^{-1}$ or a $10-\mathrm{cm}$ stubble height was maintained across all treatments (Greenquist et al., 2009; Watson et al., 2012). Stocking rates after adjustments for put-and-take cattle averaged 255, 399, and
Table I. Management variables in unfertilized control (CONT), unfertilized with cattle supplemented with dried distillers grains plus solubles (SUPP), and nitrogen fertilized (FERT) smooth bromegrass pastures at Mead, NE, from 2010 to 2011.

\begin{tabular}{|c|c|c|c|c|}
\hline \multirow[b]{2}{*}{ Item } & \multirow[b]{2}{*}{ Units } & \multicolumn{3}{|c|}{ Treatment } \\
\hline & & CONT & SUPP & FERT \\
\hline Paddock & ha & 2.90 & 2.01 & 2.01 \\
\hline Grazing season & days & 158 & 158 & 158 \\
\hline Initial stocking rate & AUD ha-l & 192 & 276 & 276 \\
\hline Final stocking rate & AUD ha-1 & 222 & 345 & 345 \\
\hline Grazing pressure $\ddagger$ & AUD $\mathrm{Mg}^{-1}$ & 32 & 37 & 33 \\
\hline Harvest efficiency§ & $\%$ & 33 & 38 & 33 \\
\hline Grazing efficiency & $\%$ & 40 & 46 & 38 \\
\hline Utilization\# & $\%$ & 83 & 82 & 89 \\
\hline
\end{tabular}

† One animal unit day (AUD) is equivalent to $10.2 \mathrm{~kg}$ dry matter, the amount of dry matter a $454 \mathrm{~kg}$ animal consumes in I $\mathrm{d}$.

$\ddagger$ Cumulative grazing pressure in SUPP assumed an herbage intake of $7.4 \mathrm{~kg} \mathrm{~d}^{-1}$ (Greenquist et al., 2009).

$\S$ Harvest efficiency $=\mathrm{kg}$ seasonal herbage intake/kg annual herbage accumulation $\times 100$. Harvest efficiency in SUPP was adjusted for less daily herbage intake.

T) Grazing efficiency = kg seasonal herbage intake/(kg annual herbage accumulation- $\mathrm{kg}$ residual herbage) $\times 100$. Grazing efficiency in SUPP was adjusted for less daily herbage intake.

\# Utilization $=100-(\mathrm{kg}$ residual herbage $/ \mathrm{kg}$ annual herbage accumulation $\times 100)$.

387 AUD ha $^{-1}$ in CONT, SUPP, and FERT pastures, respectively, from 2005 to 2009 (Watson et al., 2012) and 222, 345, and $345 \mathrm{AUD} \mathrm{ha}^{-1}$ in CONT, SUPP, and FERT, respectively, in 2010 and 2011 (Moore et al., 2012). Pasture management aimed to maintain similar cumulative grazing pressure across treatments. Harvest efficiency, the proportion of total herbage intake relative to annual herbage accumulation, ranged from 33 to $38 \%$. Grazing efficiency, the proportion of total herbage intake relative to total herbage that disappeared, ranged from 38 to $46 \%$. Utilization, the proportion of total herbage that disappeared relative to annual herbage accumulation, ranged from 82 to $89 \%$.

The soil was a Sharpsburg silty clay loam (fine, smectitic, mesic Typic Argiudoll). Soil collected to a 0 - to $15-\mathrm{cm}$ depth in October 2010 contained 4.0\% organic matter, $\mathrm{pH}$ of 5.5, $753 \mathrm{mg} \mathrm{K} \mathrm{kg}^{-1}$, and $16 \mathrm{mg} \mathrm{P} \mathrm{kg}^{-1}$ (Mehlich III). While availability of soil nutrients varied with distance from water tanks and supplemental feed bunks placed near the water tanks, there was neither significant treatment nor treatment $\times$ distance interactions on soil $\mathrm{pH}$, organic matter, $\mathrm{P}$, or $\mathrm{K}$. Therefore, $\mathrm{P}$ and $\mathrm{K}$ were assumed to be insignificant with respect to herbage accumulation and presence of pasture plant species, and thus were not applied as fertilizer in the treatments. Other than digging out thistles and spot spraying around water tanks and feed bunks, broadleaf weed control also was minimal and not in sampled areas.

\section{Nitrogen Balance}

Before 2005, the site had been fertilized annually with $90 \mathrm{~kg} \mathrm{~N} \mathrm{ha}^{-1}$ and grazed heavily from May to October (Greenquist et al., 2009). During this experiment, urea was surface applied to FERT paddocks in late March to early April of each year. Nitrogen inputs through DDGS fed to cattle and fertilizer were 0,43 , and $90 \mathrm{~kg} \mathrm{ha}^{-1} \mathrm{yr}^{-1}$ in CONT, SUPP, and FERT pastures, respectively (Table 2). Atmospheric deposition supplied an estimated $7 \mathrm{~kg} \mathrm{~N} \mathrm{ha}^{-1} \mathrm{yr}^{-1}$ equally across treatments (National Atmospheric Deposition Program, 
Table 2. Nitrogen balance in smooth bromegrass pastures from 2010-20II at Mead, NE.

\begin{tabular}{|c|c|c|c|c|}
\hline \multirow[b]{2}{*}{ Item } & \multirow[b]{2}{*}{ Source } & \multicolumn{3}{|c|}{ Treatment } \\
\hline & & CONTt & SUPP & FERT \\
\hline & & 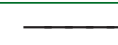 & $-\mathrm{kg} \mathrm{ha}^{-1}$ & 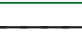 \\
\hline \multirow[t]{4}{*}{$\mathrm{N}$ input } & Fertilizer & 0 & 0 & 90 \\
\hline & DDGS $\ddagger$ & 0 & 43 & 0 \\
\hline & Deposition§ & 7 & 7 & 7 \\
\hline & Total & 7 & 50 & 97 \\
\hline \multirow[t]{3}{*}{$\mathrm{N}$ consumption } & Herbageף & 55 & 66 & 97 \\
\hline & DDGS & 0 & 43 & 0 \\
\hline & Total & 55 & 109 & 97 \\
\hline $\mathrm{N}$ retention\# & & 5 & 9 & 7 \\
\hline $\mathrm{N}$ excretion ${ }^{\prime} \dagger$ & & 50 & 100 & 90 \\
\hline $\mathrm{N}$ balance $\ddagger \ddagger$ & & 2 & 41 & 90 \\
\hline
\end{tabular}

$\dagger$ CONT, unfertilized control; SUPP, unfertilized with cattle supplemented with dried distillers grains plus solubles; FERT, nitrogen fertilized. DDGS, dried distillers grains plus solubles.

$\ddagger D D G S \mathrm{~N}$ fed $=\mathrm{kg} \mathrm{AUD}^{-1} \times \% \mathrm{~N} \times$ final stocking rate. Each animal unit was supplemented with $2.7 \mathrm{~kg}$ DDGS d ${ }^{-1}$ ( $0.6 \%$ of body weight). DDGS contained $46 \mathrm{~g} \mathrm{~N} \mathrm{~kg}^{-1}$ in 2010-2011.

$\S$ Total atmospheric $\mathrm{N}$ deposition retrieved from National Atmospheric Deposition Program (http://nadp.sws.uiuc.edu/, accessed 9 Jan. 2013).

I Herbage $\mathrm{N}$ consumption $=\%$ herbage $\mathrm{N} \times$ herbage intake $\left(\mathrm{kg} A \cup D^{-1}\right) \times$ stocking rate (AUD ha-1); $\%$ herbage $\mathrm{N}$ was $2.45,2.60$, and 2.78 in CONT, SUPP, and FERT, respectively (Greenquist et al., 2011).

$\#$ Nitrogen retention $=\mathrm{N}$ retained $A \cup D^{-1} \times$ stocking rate. Values for $\mathrm{N}$ retained $A \cup D^{-1}$ were calculated from NRC (1996) equations and reported by Greenquist et al. (20II).

$\dagger \dagger$ Nitrogen excretion $=\mathrm{N}$ consumption $-\mathrm{N}$ retention .

$\ddagger \ddagger N$ balance (surplus) $=$ total $N$ inputs $-\mathrm{N}$ retention

2012). Within SUPP, $61 \%$ and $39 \%$ of total $N$ consumed was derived from herbage and DDGS, respectively (Greenquist et al., 2011). Nitrogen retention by animals was $5.3,10.5$, and $8.0 \mathrm{~kg} \mathrm{ha}^{-1} \mathrm{yr}^{-1}$ in CONT, SUPP, and FERT pastures, respectively, from 2005 to 2007 (Greenquist et al., 2011). With use of values for $\mathrm{N}$ retained $\mathrm{AUD}^{-1}$ from this earlier research, we computed $\mathrm{N}$ retention to be 5,9 , and $7 \mathrm{~kg} \mathrm{ha}^{-1}$ in CONT, SUPP, and FERT, respectively, in 2010 to 2011 . The slight decline in $\mathrm{N}$ retention across treatments in 2010 to $2011 \mathrm{com}$ pared to 2005 to 2007 resulted from a reduction in final stocking rates. Nitrogen excretion was $100 \%$ greater in SUPP than CONT and $11 \%$ greater in SUPP than FERT. Nitrogen balance of pastures, however, was dominated by $\mathrm{N}$ inputs rather than outflow of $\mathrm{N}$ retained by cattle and was $120 \%$ greater in FERT than SUPP.

\section{Herbage Mass and Accumulation}

Herbage mass was determined in June and October 2010 and 2011 by clipping one $0.36-\mathrm{m}^{2}$ quadrat at a $1-\mathrm{cm}$ stubble height within each of $10,1.77-\mathrm{m}^{2}$ cattle exclosures. Exclosures were randomly distributed to new locations within a paddock of each experimental unit after fertilizer was applied in spring of each year. Redistribution of exclosures to new locations annually allowed an assessment of how reduction of $\mathrm{N}$ input in earlier years affected herbage mass and accumulation. Harvests in June coincided with peak herbage mass of smooth bromegrass. The same areas were harvested again in October to measure amount of growth since the June harvest. After clipping, herbage mass samples were put in a forced-air oven at $60^{\circ} \mathrm{C}$ for $60 \mathrm{~h}$ and then weighed. Annual herbage accumulation was computed from the sum of herbage mass from the June and October harvests.

\section{Presence of Plant Species and Functional Groups}

Presence of individual plant species was visually assessed and recorded within 60 randomly placed, $0.1-\mathrm{m}^{2}$ quadrats within one of the six paddocks in each experimental unit on 7 Oct. 2010 and 13 Oct. 2011. Quadrats were not placed within $1 \mathrm{~m}$ of fences and a 5-m zone near water sources, feed bunks, and entrances to the pastures. During these assessments, a cumulative list of species recorded among the quadrats was compiled. After all quadrats were sampled, a spreadsheet with species listed in columns and quadrats listed in rows was developed, and the presence and absence of a species within a quadrat was noted with scores of one and zero, respectively. These data were then averaged by plant species and grouped by functional group (cool-season perennial grasses and grass-like plants, perennial forbs, annual grasses, annual forbs, and total annuals) to determine means of each experimental unit.

\section{Statistical Analysis}

Data were analyzed using mixed model procedures (SAS Inst., Cary, NC). Treatment, year, and treatment $\times$ year interactions were considered fixed factors, and the block $\times$ treatment interaction was considered a random factor. When treatment $\times$ year interactions were significant, data were analyzed by year with the general linear models procedure and differences between treatment means were compared with the least significant difference procedure. Significant differences were declared at the $P<0.05$ probability level.

\section{RESULTS \\ Weather}

Cumulative precipitation from October through September totaled $932 \mathrm{~mm}$ in 2009 to 2010 compared to $603 \mathrm{~mm}$ in 2010 to 2011 (Fig. 1). Average annual precipitation from 1968 to 2011 was $719 \mathrm{~mm}$ for the location (High Plains Regional Climate Center, 2012). Snowfall also accounted for precipitation from January through March with $33 \mathrm{~cm}$ in 2010, $57 \mathrm{~cm}$ in 2011, and $32 \mathrm{~cm}$ for the long term from 1968 to 2011. Average daily temperature was $10.0^{\circ} \mathrm{C}$ in 2010 and $9.9^{\circ} \mathrm{C}$ in 2011 , matching the average daily temperature of $10.0^{\circ} \mathrm{C}$ from 1968 to 2011 (High Plains Regional Climate Center, 2012).

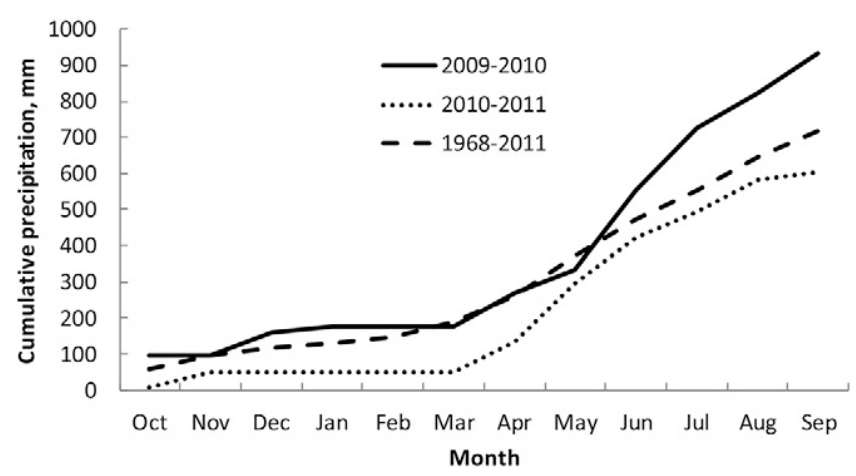

Fig. I. Cumulative precipitation $(\mathrm{mm})$ from October through September for 2009 to 2010,2010 to 2011 , and 1968 to 2011 at Mead, NE. 
Table 3. Analysis of variance and mean comparisons of herbage mass from June and October harvests, annual herbage accumulation, and the percentage of herbage accumulation by June in unfertilized control (CONT), unfertilized with cattle supplemented with dried distillers grains plus solubles (SUPP), and nitrogen fertilized (FERT) pastures at Mead, NE, in 2010 and $201 \mathrm{I}$.

\begin{tabular}{|c|c|c|c|c|c|}
\hline \multirow[b]{2}{*}{ Effect } & \multirow[b]{2}{*}{ dff } & \multicolumn{4}{|c|}{ Herbage mass and accumulation } \\
\hline & & June & October & Total & $\%$ by June \\
\hline & & \multicolumn{4}{|c|}{$F$ value } \\
\hline Treatment $(\mathrm{T})$ & 2,6 & $65.6 * * *$ & 0.9 & $38.0 * * *$ & II.I** \\
\hline Year (Y) & $\mathrm{I}, 6$ & 0.6 & $231.6 * * *$ & $79.8 * * *$ & $187.5^{* * *}$ \\
\hline \multirow[t]{2}{*}{$\mathrm{T} \times \mathrm{Y}$} & 2,6 & 0.9 & 0.0 & 0.9 & 1.9 \\
\hline & & \multicolumn{4}{|c|}{$\mathrm{Mg} \mathrm{ha}^{-1}$} \\
\hline \multirow[t]{4}{*}{ Treatment } & CONT $\ddagger$ & 4.27 & 2.41 & 6.87 & 66.5 \\
\hline & SUPP & 4.29 & 2.47 & 6.80 & 66.2 \\
\hline & FERT & 7.49 & 2.68 & 10.58 & 76.0 \\
\hline & LSD & 0.86 & $\mathrm{~ns} \S$ & 1.49 & 5.3 \\
\hline \multirow[t]{3}{*}{ Year } & 2010 & 5.28 & 1.21 & 6.83 & 81.2 \\
\hline & 2011 & 5.42 & 3.83 & 9.33 & 57.9 \\
\hline & LSD & ns & 0.46 & 0.16 & 6.1 \\
\hline
\end{tabular}

** Significance at $\leq 0.010$ probability level.

$* * *$ Significance at $\leq 0.001$ probability level.

$\dagger$ Numerator followed by denominator degrees of freedom.

$\ddagger$ CONT, unfertilized control; SUPP, unfertilized with cattle supplemented with

dried distillers grains plus solubles; FERT, nitrogen fertilized.

$\S \mathrm{ns}$, not significant.

\section{Herbage Mass and Accumulation}

Herbage mass and accumulation depended on treatment and year, but no treatment $\times$ year interactions occurred (Table 3 ). Input of $\mathrm{N}$ fertilizer in spring in FERT resulted in $55 \%$ more annual herbage accumulation relative to CONT and SUPP where no $\mathrm{N}$ fertilizer was applied (Table 3). Differences in urinary $\mathrm{N}$ excretion between CONT and SUPP in earlier years of this experiment (Greenquist et al., 2011; Table 2) had no effect on herbage accumulation in 2010 and 2011. Differences in the June harvest which occurred at peak herbage mass of smooth bromegrass were responsible for greater annual herbage accumulation in FERT than in CONT and SUPP. No differences existed between treatments in herbage harvested in October. Yield of herbage harvested in October, however, depended on year. A hailstorm in September 2010 destroyed existing herbage and reduced yield in the October 2010 harvest by 68\% relative to the October 2011 harvest. Annual herbage accumulation was 27\% less in 2010 than 2011.

\section{Presence of Pasture Species and Functional Groups}

Neither treatment nor year affected presence of perennial graminoids or perennial forbs in the pastures (Table 4). Smooth bromegrass, Kentucky bluegrass (Poa pratensis L.), and perennial graminoids as a whole were present in 99.8, 11.7, and $99.9 \%$ of $0.1-\mathrm{m}^{2}$ pasture quadrats, respectively. Treatment and year also did not affect tall fescue [Schedonorus phoenix (Scop.) Holub], Scribner panicum [Dicanthelium oligosanthes (J.A. Schultes) Gould var. scribnerianum (Nash) Gould], and yellow nutsedge (Cyperus esculentus L.), perennial graminoids that were present in $<1 \%$ of quadrats. Dandelion (Taraxacum officinale G.H. Weber ex Wiggers) and perennial forbs as a whole were present in 4.6 and $10.9 \%$ of quadrats, respectively.
Table 4. Analysis of variance of presence of perennial graminoids and perennial forbs at a $0.1-\mathrm{m}^{2}$ scale in unfertilized control (CONT), unfertilized with cattle supplemented with dried distillers grains plus solubles (SUPP), and nitrogen fertilized (FERT) pastures at Mead, NE.

\begin{tabular}{|c|c|c|c|c|c|c|}
\hline \multirow[b]{2}{*}{ Effect } & \multirow[b]{2}{*}{ dff } & \multicolumn{3}{|c|}{ Perennial graminoids } & \multicolumn{2}{|c|}{ Perennial forbs } \\
\hline & & $\begin{array}{c}\text { Smooth } \\
\text { bromegrass }\end{array}$ & $\begin{array}{l}\text { Kentucky } \\
\text { bluegrass }\end{array}$ & Total & $\begin{array}{l}\text { Common } \\
\text { dandelion }\end{array}$ & Total \\
\hline & & & $F$ valu & e - & & $\overline{-}$ \\
\hline Treatment $(\mathrm{T})$ & 2,6 & 0.5 & 1.0 & 1.0 & 1.1 & 0.8 \\
\hline Year (Y) & 1,6 & 0.0 & 1.6 & 1.0 & 0.0 & 0.3 \\
\hline $\mathrm{T} \times \mathrm{Y}$ & 2,6 & 1.5 & 0.1 & 1.0 & 0.5 & 0.2 \\
\hline
\end{tabular}

$\dagger$ Numerator followed by denominator degrees of freedom.

Neither dandelion nor perennial forbs, which also include included field bindweed (Convolvulus arvensis L.), Virginia groundcherry (Physalis virginiana P. Miller), and gray-green woodsorrel (Oxalis dillenii Jacq.) present in $<1 \%$ of quadrats, were affected by treatment or year (Table 4).

Treatment had its greatest effect on presence of annual foxtail, annual graminoids, and annuals as a whole (Table 5). Foxtail, annual graminoids, and annuals as a whole had greater presence in CONT than FERT in both years. Horseweed [Conyza canadensis (L.) Cronq.] and annual forbs as a functional group, which were present in 1.1 and $6.1 \%$ of quadrats, respectively, were not significantly affected by treatment in 2010, but both had greater presence in CONT than FERT in 2011. In general, presence of foxtail, annual graminoids, horseweed, annual forbs, and annuals as a whole was intermediate in SUPP relative to CONT and FERT in both years. Dry growing conditions in spring 2011 and a preceding hailstorm in September 2010 that destroyed most new growth of smooth bromegrass in the pastures likely contributed to the increased presence of annuals from 2010 to 2011 . Annual graminoid and forb species present in $<1 \%$ of quadrats included barnyardgrass [Echinochloa crus-galli (L.) Beauv.], fall panicum (Panicum dichotomiflorum Michx.), stinkgrass [Eragrostis cilianensis (All.) Lut. ex Janchen], buffalobur (Solanum rostratum Dunal), common ragweed (Ambrosia artemisifolia L.), common lambsquarters (Chenopodium album L.), prostrate vervain (Verbena bracteata Lag. and Rodr.), common knotweed (Polygonum arenastrum Jord. ex Boreau), Pennsylvania smartweed (Polygonum pensylvanicum L.), redroot pigweed (Amaranthus retroflexus L.), and spotted spurge (Euphorbia maculata L.). Their presence was not affected by treatment or year.

\section{DISCUSSION}

With growth of the corn ethanol industry and loss of pastureland in the north central region of the United States in recent years, beef cattle producers have supplemented DDGS, an excellent source of crude protein and digestible dry matter, for forage in beef cattle diets (Klopfenstein et al., 2008). In an experiment in Nebraska, supplementation of DDGS to beef cattle grazing unfertilized smooth bromegrass pasture was found to increase animal production (Greenquist et al., 2009), improve $\mathrm{N}$ use efficiency (Greenquist et al., 2011), and provide better financial returns (Watson et al., 2012) than unsupplemented beef cattle grazing fertilized and unfertilized smooth bromegrass pasture. Response of pasture vegetation and soil to 
Table 5. Analysis of variance of presence of annual graminoids, annual forbs, and annuals as a whole at a $0.1-\mathrm{m}^{2} \mathrm{scale}$ in unfertilized control (CONT), unfertilized with cattle supplemented with dried distillers grains plus solubles (SUPP), and nitrogen fertilized (FERT) pastures at Mead, NE.

\begin{tabular}{|c|c|c|c|c|c|c|}
\hline \multirow[b]{2}{*}{ Effect } & \multirow[b]{2}{*}{ dff } & \multicolumn{2}{|c|}{ Annual graminoids } & \multicolumn{2}{|c|}{ Annual forbs } & \multirow{2}{*}{$\begin{array}{c}\text { Annuals } \\
\text { Total }\end{array}$} \\
\hline & & Foxtail & Total & Horseweed & Total & \\
\hline & & & & $F$ value & 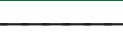 & 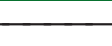 \\
\hline Treatment ( $\mathrm{T})$ & 2,6 & $5.9^{*}$ & $5.9 *$ & $7.5^{*}$ & $7.7^{*}$ & $7.4^{*}$ \\
\hline Year $(\mathrm{Y})$ & $\mathrm{I}, 6$ & $46.0 * * *$ & $66.5^{* * *}$ & $39.7 * * *$ & $101.3^{* * * *}$ & $56.7^{* * *}$ \\
\hline $\mathrm{T} \times \mathrm{Y}$ & 2,6 & $7.3^{*}$ & $9.4^{*}$ & $8.5^{*}$ & $20.1 * *$ & $6.4^{*}$ \\
\hline \multirow[t]{4}{*}{2010} & CONT $\ddagger$ & 28.3 & 29.4 & 3.3 & 11.7 & 38.3 \\
\hline & SUPP & 13.4 & 16.7 & 0.0 & 5.0 & 20.6 \\
\hline & FERT & 4.4 & 6.1 & 0.0 & 1.7 & 7.2 \\
\hline & LSD & 15.4 & 17.1 & nsई & ns & 24.9 \\
\hline \multirow[t]{4}{*}{2011} & CONT & 92.8 & 93.3 & 73.9 & 75.6 & 97.8 \\
\hline & SUPP & 64.4 & 70.0 & $4 I . I$ & 46.7 & 77.2 \\
\hline & FERT & 13.9 & 17.2 & 7.2 & 8.3 & 21.7 \\
\hline & LSD & 46.7 & 44.9 & 52.5 & 3.5 & 37.7 \\
\hline
\end{tabular}

* Significance at $\leq 0.050$ probability level.

** Significance at $\leq 0.010$ probability level.

$* * *$ Significance at $\leq 0.00$ I probability level.

$\dagger$ Numerator followed by denominator degrees of freedom.

$\ddagger$ CONT, unfertilized control; SUPP, unfertilized with cattle supplemented with dried distillers grains plus solubles; FERT, nitrogen fertilized.

$\S \mathrm{ns}$, not significant.

the changing of amount and form of $\mathrm{N}$ input in these management strategies, however, remained unknown.

We hypothesized $\mathrm{N}$ cycling through cattle supplemented with DDGS which contained $43 \mathrm{~kg} \mathrm{~N} \mathrm{ha}^{-1} \mathrm{yr}^{-1}$ (SUPP), would increase herbage mass and accumulation relative to CONT and maintain similar plant species as FERT pastures. In the sixth and seventh years of this ongoing experiment, we found SUPP had similar herbage mass and accumulation as CONT. Despite twice as much $\mathrm{N}$ excretion to the pasture in SUPP $\left(100 \mathrm{~kg} \mathrm{ha}^{-1} \mathrm{yr}^{-1}\right)$ than CONT $\left(50 \mathrm{~kg} \mathrm{ha}^{-1} \mathrm{yr}^{-1}\right)$, N did not carry over and positively affect herbage accumulation in subsequent years. While greater herbage accumulation was observed in SUPP (7.30 Mg ha ${ }^{-1}$ ) relative to CONT (6.56 $\mathrm{Mg} \mathrm{ha}^{-1}$ ) from 2008 to 2009 (Watson et al., 2012), the difference was small relative to positive effects of $\mathrm{N}$ fertilizer application in spring (FERT: $9.43 \mathrm{Mg} \mathrm{ha}^{-1}$ ). The small herbage response to $\mathrm{N}$ excreted in earlier years of the experiment was likely due to immobilization of urinary $\mathrm{N}$ in organic matter or loss of it through volatilization, denitrification, or leaching (Ball and Ryden, 1984). The small response also may have been due to inefficient use by smooth bromegrass of $\mathrm{N}$ supplied through excreta deposition throughout the grazing season as opposed to urea applied as fertilizer in spring (Power, 1988). Cessation of $\mathrm{N}$ fertilizer input in CONT and SUPP reduced annual herbage accumulation by $35 \%$ relative to FERT from 2010 to 2011, a finding that supports the initial stocking rates used in these systems and previous research on smooth bromegrass (Colville et al., 1963).

Increased excretion of $\mathrm{N}$ in SUPP had mixed effects on presence of pasture plant species. In 2010, presence of both perennial and annual plant species was similar in SUPP and FERT. In 2011, however, presence of foxtail, annual graminoids, and annuals were greater in SUPP than FERT pastures. The CONT pastures had increased presence of foxtail, annual graminoids, and annuals as a whole relative to FERT pastures in both years. Changing amount and form of $\mathrm{N}$ input in these management strategies had no affect on presence of perennial pasture species. While Kentucky bluegrass is a perennial grass commonly found in temperature pasture studies (Guretzky et al., 2005; Goslee et al., 2009), we did not find evidence that Kentucky bluegrass would increase with reduction of $\mathrm{N}$ input in CONT or a change of $\mathrm{N}$ amount and form in SUPP. Frequency of occurrence of Kentucky bluegrass was similar among treatments and years, averaging $11.7 \%$.

Increased presence of foxtail, annual graminoids, and annuals in CONT and SUPP suggested the 50 and $100 \mathrm{~kg} \mathrm{~N} \mathrm{ha}^{-1}$ cycled to pasture in urine throughout the grazing season in these treatments was insufficient to maintain smooth bromegrass dominance relative to spring fertilizer application. Studies of temperate grasslands have reported that $\mathrm{N}$ fertilizer input enables perennial cool-season grasses to dominate by reducing light availability at the ground surface and limiting establishment of new species (Tilman, 1987, 1993; Foster and Gross, 1998; Vinton and Goergen, 2006). Annuals such as foxtail are well adapted to pastures, but their seed often lie dormant in the seed bank until favorable disturbances and environmental conditions promote germination and emergence (Dekker, 2003). Their emergence in pastures may be difficult to predict as composition of aboveground vegetation bears little resemblance to composition of soil seed banks where annual grasses and forbs dominate (Tracy and Sanderson, 2000; Sanderson et al., 2007; Goslee et al., 2009). Recent experiments have focused on the role of forage plant species richness and diversity as a means of resisting annual and perennial weeds, including forbs and grasses, in pastures. A study conducted in Missouri found that aboveground weed abundance declined as evenness of forage species distribution increased in experimental pasture plant communities (Tracy et al., 2004). A survey of pastures across the northeastern United States found weed abundance decreased as forage species diversity increased (Tracy and Sanderson, 2004). These researchers concluded that maintenance of $>1500 \mathrm{~kg} \mathrm{ha}^{-1}$ of herbage mass and an evenly distributed 
array of forage species reduces weed invasion (Tracy and Sanderson, 2004). Our study revealed annual $\mathrm{N}$ fertilizer input of $90 \mathrm{~kg} \mathrm{ha}^{-1}$ in FERT provided nearly complete suppression of annual and perennial weeds and 55\% greater annual herbage accumulation relative to unfertilized pasture.

The animal-to-forage relationship over time has been identified as a key factor affecting weed invasion in pastures (Harker et al., 2000). Calculation of cumulative grazing pressure expresses this relationship in a standardized form for comparisons across treatments (Smart et al., 2010; Allen et al., 2011). In our experiment, cumulative grazing pressure ranged from 32 to $37 \%$ and was similar to that reported for heavily-stocked rangeland (40\%) in the Great Plains (Smart et al., 2010). Although utilization was high (82-89\%), our experiment was conducted on a highly productive site. Harvest efficiency (33-38\%) was comparable to heavily-stocked rangeland (32-42\%), but grazing efficiency $(38-46 \%)$ was more comparable to light- and moderately-stocked rangeland (39 and 49\%, respectively) than heavily-stocked (61\%) rangeland (Smart et al., 2010). Lower grazing efficiency in our experiment suggested more herbage was lost to trampling, fouling, and senescence relative to herbage intake. Herbage intake may have declined after spring as higher quality, vegetative growth of smooth bromegrass slowed during summer. Herbage accumulation was 66.2 to $76.0 \%$ complete by 25 June (Table 3 ) despite the grazing season continuing into late September and early October.

Although N cycling through SUPP did not increase annual herbage accumulation relative to CONT from 2010 to 2011 and suppress annual weeds as well as FERT, steer average daily weight gains and total weight gains per hectare have been better with SUPP than CONT and FERT over the course of this experiment (Greenquist et al., 2009; Moore et al., 2012; Watson et al., 2012). Furthermore, SUPP enabled higher stocking rates than CONT (Greenquist et al., 2009; Watson et al., 2012), while improving $\mathrm{N}$ use efficiency on per steer and per hectare bases (Greenquist et al., 2011) and economic performance (Watson et al., 2012) relative to CONT and FERT. Cessation of N fertilizer input in CONT reduced annual herbage accumulation, increased presence of annuals, and supported less total steer gain ha ${ }^{-1}$ relative to FERT (Greenquist et al., 2009; Moore et al., 2012; Watson et al., 2012). Producers have an incentive to fertilize pastures at land prices below $\$ 26 \mathrm{AUM}^{-1}$ and fertilizer prices below $\$ 1.22 \mathrm{~kg}^{-1} \mathrm{~N}$ and supplement with DDGS on unfertilized pastures at land prices below $\$ 30 \mathrm{AUM}^{-1}$ and DDGS prices of $\$ 165 \mathrm{Mg}^{-1}$ (Watson et al., 2012).

\section{CONCLUSION}

Management strategies that change amount and form of $\mathrm{N}$ inputs affect herbage accumulation and presence of plant species in pastures. After $7 \mathrm{yr}$ of this experiment, we found SUPP, CONT, and FERT maintained presence of smooth bromegrass in $99.8 \%$ of pasture quadrats. Presence of foxtail, annual graminoids, and annuals as functional groups, however, was greatest in CONT, intermediate in SUPP, and least in FERT, reflecting annual $\mathrm{N}$ input into these management systems. While CONT and SUPP did not suppress annual weeds as well as FERT pastures, they reduced $\mathrm{N}$ fertilizer use. Furthermore, $\mathrm{N}$ not retained by cattle after herbage and DDGS consumption was excreted in pastures throughout the grazing season. Although
$\mathrm{N}$ excretion was greater in SUPP $\left(100 \mathrm{~kg} \mathrm{ha}^{-1} \mathrm{yr}^{-1}\right)$ than CONT $\left(50 \mathrm{~kg} \mathrm{~N} \mathrm{ha}^{-1} \mathrm{yr}^{-1}\right)$, herbage mass and accumulation was similar in subsequent years, suggesting inefficient use or capture of $\mathrm{N}$ excreted during summer relative to spring fertilizer applications. Supply of urea fertilizer in late March to early April at $90 \mathrm{~kg} \mathrm{~N} \mathrm{ha}^{-1}$ enabled accumulation of $10.58 \mathrm{Mg} \mathrm{ha}^{-1}$ of herbage annually while limiting presence of annual graminoids and forbs in smooth bromegrass pasture. Accumulation of $6.8 \mathrm{Mg} \mathrm{ha}^{-1}$ of herbage can be expected annually in unfertilized smooth bromegrass pasture.

\section{ACKNOWLEDGMENTS}

The authors wish to thank David Guretzky and Christopher Barber for their assistance with this research. Funding assistance has been provided through the multi-state Hatch project no. NEB-61-006 Nitrogen cycling, loading, and use efficiency in forage-based livestock production systems (NC1182) and Hatch project no. NEB-22-345 Ethanol co-product utilization and fertilization effects on carbon and nitrogen cycling in pastures.

\section{REFERENCES}

Allen, V.G., C. Batello, E.J. Berretta, J. Hodgson, M. Kothmann, X. Li et al. 2011. An international terminology for grazing lands and grazing animals. Grass Forage Sci. 66:2-28. doi:10.1111/j.1365-2494.2010.00780.x

Ball, P.R., and J.C. Ryden. 1984. Nitrogen relationships in intensively managed temperate grasslands. Plant Soil 76:23-33. doi:10.1007/BF02205564

Beuselinck, P.R., J.H. Bouton, W.O. Lamp, A.G. Matches, M.H. McCaslin, C.J. Nelson et al. 1994. Improving legume persistence in forage crop systems. J. Prod. Agric. 7:311-322.

Colville, W.L., L. Chesnin, and D.P. McGill. 1963. Effect of precipitation and long-term nitrogen fertilization on nitrogen uptake, crude protein content and yield of bromegrass forage. Agron. J. 55:215-218. doi:10.2134/ agronj1963.00021962005500030002x

Dekker, J. 2003. The foxtail (Setaria) species-group. Weed Sci. 51:641-656. doi:10.1614/P2002-IR

Foster, B.L., and K.L. Gross. 1998. Species richness in a successional grassland: Effects of nitrogen enrichment and plant litter. Ecology 79:2593-2602. doi:10.1890/0012-9658(1998)079[2593:SRIASG]2.0.CO;2

Goslee, S.C., M.A. Sanderson, and J. Gonet. 2009. No persistent changes in pasture vegetation or seed bank composition after fallowing. Agron. J. 101:1168-1174. doi:10.2134/agronj2008.0243

Greenquist, M.A., T.J. Klopfenstein, W.H. Schacht, G.E. Erickson, K.J. Vander Pol, M.K. Luebbe et al. 2009. Effects of nitrogen fertilization and dried distillers grains supplementation: Forage use and performance of yearling steers. J. Anim. Sci. 87:3639-3646. doi:10.2527/jas.2009-1795

Greenquist, M.A., A.K. Schwarz, T.J. Klopfenstein, W.H. Schacht, G.E. Erickson, K.J. Vander Pol et al. 2011. Effects of nitrogen fertilization and dried distillers grains supplementation: Nitrogen use efficiency. J. Anim. Sci. 89:1146-1152. doi:10.2527/jas.2010-2902

Griffin, W.A., V.R. Bremer, T.J. Klopfenstein, L.A. Stalker, L.W. Lomas, J.L. Moyer, and G.E. Erickson. 2012. A meta-analysis evaluation of supplementing dried distillers grains plus solubles to cattle consuming foragebased diets. Prof. Anim. Sci. 28:306-312.

Guretzky, J.A., K.J. Moore, E.C. Brummer, and C.L. Burras. 2005. Species diversity and functional composition of pastures that vary in landscape position and grazing management. Crop Sci. 45:282-289.

Harker, K.N., V.S. Baron, D.S. Chanasyk, M.A. Naeth, and F.C. Stevenson. 2000. Grazing intensity effects on weed populations in annual and perennial pasture systems. Weed Sci. 48:231-238. doi:10.1614/0043-1745(2000)048[0231:GIEOW P]2.0.CO;2

Harmoney, K.R., K.J. Moore, E.C. Brummer, C.L. Burras, and J.R. George. 2001. Spatial legume composition and diversity across seeded landscapes. Agron. J. 93:992-1000. doi:10.2134/agronj2001.935992x

High Plains Regional Climate Center. 2012. Mead Agronomy Farm web data access. Univ. of Nebraska-Lincoln. www.hprcc.unl.edu/services/index. php? $\mathrm{p}=$ online (accessed 29 Mar 2012). 
Klopfenstein, T.J., G.E. Erickson, and V.R. Bremer. 2008. BOARD-INVITED REVIEW: Use of distillers by-products in the beef cattle feeding industry. J. Anim. Sci. 86:1223-1231. doi:10.2527/jas.2007-0550

Moore, S.K., C.J. Schneider, B.L. Nuttleman, D.B. Burken, T.J. Klopfenstein, G.E. Erickson et al. 2012. Strategic supplementation of dried distillers grains plus solubles to yearling steers grazing smooth bromegrass. 2013 Nebraska Beef Cattle Report. Univ. of Nebraska. Lincoln. http://beef. unl.edu/web/beef/nebeefreport2013 (accessed 7 Nov. 2012). p. 31-32.

National Atmospheric Deposition Program. 2012. Inorganic nitrogen wet deposition from nitrate and ammonium, 2010 and 2011. Illinois State Water Survey. http://nadp.sws.uiuc.edu/ntn/annualmapsbyyear.aspx (accessed 20 Feb. 2013).

National Research Council. 1996. Nutrient requirements of beef cattle. 7th rev. ed. Natl. Academy Press, Washington, DC.

Power, J.F. 1988. Seasonal changes in smooth bromegrass top and root growth and fate of fertilizer nitrogen. Agron. J. 80:740-745. doi:10.2134/agronj $1988.00021962008000050009 x$

Sanderson, M.A., S.C. Goslee, K.D. Klement, and K.J. Soder. 2007. Soil seed bank composition in pastures of diverse mixtures of temperate forages. Agron. J. 99:1514-1520. doi:10.2134/agronj2006.0371

Sleugh, B., K.J. Moore, J.R. George, and E.C. Brummer. 2000. Binary legumegrass mixtures improve forage yield, quality, and seasonal distribution. Agron. J. 92:24-29. doi:10.2134/agronj2000.92124x

Smart, A.J., J.D. Derner, J.R. Hendrickson, B.H. Dunn, E.M. Mousel, P.S. Johnson et al. 2010. Effects of grazing pressure on efficiency of grazing on North American Great Plains rangelands. Rangeland Ecol. Manag. 63:397-406. doi:10.2111/REM-D-09-00046.1
Tilman, D. 1987. Secondary succession and the pattern of plant dominance along experimental nitrogen gradients. Ecol. Monogr. 57:189-214. doi: $10.2307 / 2937080$

Tilman, D. 1993. Species richness of experimental productivity gradients: How important is colonization limitation? Ecology 74:2179-2191. doi: $10.2307 / 1939572$

Tracy, B.J., I.J. Renne, J. Gerrish, and M.A. Sanderson. 2004. Effects of plant diversity on invasion of weed species in experimental pasture communities. Basic Appl. Ecol. 5:543-550. doi:10.1016/j.baae.2004.08.007

Tracy, B.J., and M.A. Sanderson. 2000. Seedbank diversity in grazing lands of the Northeast United States. J. Range Manage. 53:114-118. doi:10.2307/4003401

Tracy, B.J., and M.A. Sanderson. 2004. Forage productivity, species evenness and weed invasion in pasture communities. Agric. Ecosyst. Environ. 102:175-183. doi:10.1016/j.agee.2003.08.002

Vinton, M.A., and E.M. Goergen. 2006. Plant-soil feedbacks contribute to persistence of Bromus inermis in tallgrass prairie. Ecosystems 9:967-976. doi:10.1007/s10021-005-0107-5

Vogel, K.P., K.J. Moore, and L.E. Moser. 1996. Bromegrasses. In: L.E. Moser et al., editors, Cool-season forage grasses. ASA, CSSA, and SSSA. Madison, WI. p. 535-567.

Waller, S.S., L.E. Moser, and B. Anderson. 1986. A guide for planning and analyzing a year-round forage program. EC86-113. Univ. of Nebraska Coop. Ext. Serv., Lincoln.

Watson, A.K., T.J. Klopfenstein, W.H. Schacht, G.E. Erickson, D.R. Mark, M.K. Luebbe, et al. 2012. Smooth bromegrass pasture beef growing systems: Fertilization strategies and economic analysis. Prof. Anim. Sci. $28: 443-451$. 